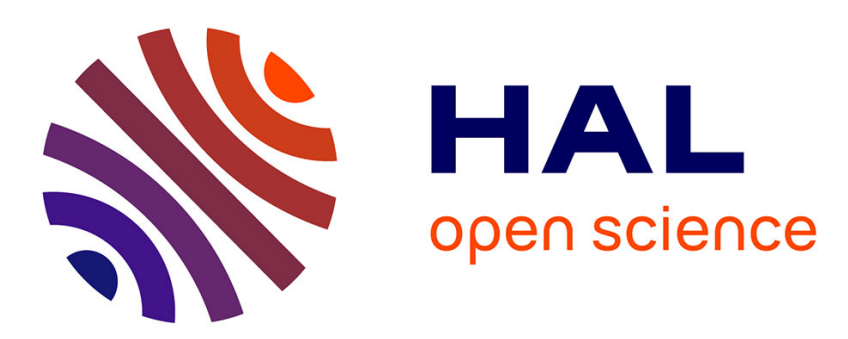

\title{
New Perspectives for Climate Justice: District Court of The Hague, 24 June 2015, Urgenda Foundation versus the Netherlands
}

Christel Cournil, Anne-Sophie Tabau

\section{- To cite this version:}

Christel Cournil, Anne-Sophie Tabau. New Perspectives for Climate Justice: District Court of The Hague, 24 June 2015, Urgenda Foundation versus the Netherlands. Journal for European Environmental \& Planning Law, 2015, 12 (3-4), pp.221-240. 10.1163/18760104-01204001 • hal-01758896

\section{HAL Id: hal-01758896 https://hal.science/hal-01758896}

Submitted on 5 Apr 2018

HAL is a multi-disciplinary open access archive for the deposit and dissemination of scientific research documents, whether they are published or not. The documents may come from teaching and research institutions in France or abroad, or from public or private research centers.
L'archive ouverte pluridisciplinaire HAL, est destinée au dépôt et à la diffusion de documents scientifiques de niveau recherche, publiés ou non, émanant des établissements d'enseignement et de recherche français ou étrangers, des laboratoires publics ou privés. 


\title{
New Perspectives for Climate Justice
}

\section{District Court of The Hague, 24 June 2015, Urgenda Foundation versus the Netherlands}

\section{A. S. Tabau et C. Cournil (Université Paris 13)}

\begin{abstract}
The climate mitigation target of the Netherlands violating the State's duty of care, it has to be elevated to reach at least -25\% in 2020 compared to 1990. This ruling of the District Court of the Hague in the case opposing the NGO Urgenda to the Netherlands marks a turning point of climate justice. Although limited in its scope, it contributes to the subjectivization of climate justice actors but also to the objectivization of associated liability, opening the way for a "dialogue of judges" and influence on international negotiations.
\end{abstract}

Key words: climate change, mitigation target, justice, liability, review of validity, NGO, State.

\section{Introduction}

The District Court of The Hague's decision on 24 June 2015 in the Urgenda versus the Netherlands ${ }^{1}$ case has been described as historic as regards its contribution to climate justice. Although limited in several respects: in terms of its scope ratione personae to the Netherlands, ratione materiae to this country's policies on the mitigation of greenhouse gas (GHG) emissions, and ratione temporis up to 2020; its impact could far exceed this range through ripple effects on other jurisdictions, even within the framework of international negotiations on climate change.

Climate justice raises equivocal social and ethical issues. Indeed, theorists disagree on which direction climate justice should take, ${ }^{2}$ on who is primarily accountable ${ }^{3}$ and who should

\footnotetext{
${ }^{1}$ http://uitspraken.rechtspraak.nl/inziendocument?id=ECLI:NL:RBDHA:2015:7196\&keyword=urgenda (English version of the judgment which this commentary refers to).

${ }^{2}$ For example, R. Cox, advocates an "energy revolution" as quickly and efficiently as possible, to prevent the already critical condition of the Earth's environment from leading to the fall of Western societies. He considers, in this respect, that justice has a particular role to play. See R. Cox, Revolution justified, Planet Prosperity Foundation, 2012, 328 p. (http://www.revolutionjustified.org/).

${ }^{3}$ As described in the "Oslo principles on global climate change obligations", developed and adopted by a group of eminent jurists, regarding States and enterprises, with emphasis on the special role of human rights and the precautionary principle (http://www.osloprinciples.org/principles/).
} 
be its main recipients. ${ }^{4}$ Concepts and principles with uncertain definitions (polluter pays, common but differentiated responsibilities, equity, etc.) are also at the heart of climate justice issues. ${ }^{5}$ Arguments between States over concrete definitions and implications have stalled the ongoing international negotiations on the evolution of the international regime to tackle climate change, negotiations that are expected to lead to a new multilateral agreement in December 2015 in Paris. The weak compromise that emerged from the Warsaw 2013 and Lima 2014 climate change conferences was that each party should define its own "national contribution" and should provide justification for why its proposed GHG emission reduction target is fair and equitable. However, this strategy of voluntary restraint does not seem to have generated sufficient momentum to achieve the level of action recommended by scientists at the Intergovernmental Panel on Climate Change (IPCC), and it is unlikely that the few months remaining before the Paris Conference will allow enough time for the gap to be closed.

In law, climate justice refers to the concept of responsibility, its implementation aims to ensure respect for the law, attaching legal consequences to a failure to comply. However, this legal liability is multifaceted. Many actors may be considered responsible for climate change (States, individually or collectively, businesses, individuals, international institutions, etc....). ${ }^{6}$ Furthermore, responsibility can vary depending on the nature of the obligations breached and the resultant consequences (international, domestic, contractual, tort, administrative, civil, criminal responsibility) and depending on the objectives (for contributing to the problem, to address it, to prevent it, to promote distributive justice, current or future, etc.). Finally, this responsibility may or may not be held through litigation, which if undertaken in climate cases does not necessarily aim to establish liability.

Internally, climate justice has indeed triggered a range of contentious action throughout the world. ${ }^{7}$ However, lawsuits were not always filed in support to climate justice, in its moral

\footnotetext{
${ }^{4}$ For the various perspectives of ethical debates: see P.-Y. Néron, Penser la justice climatique, Éthique publique 2012 (1), published online on 17 February 2013 (http://ethiquepublique.revues.org/937).

${ }^{5}$ See, in this respect, Article $3 \S 1$ of the United Nations Framework Convention on Climate Change.

6 S. Caney, Cosmopolitan Justice, Responsibility, and Global Climate Change, Leiden Journal of International Law 2005 (18), pp. 747-775.

${ }^{7}$ Bar Association Climate Change Justice and Human Rights Task Force, Achieving Justice and Human Rights in an Era of Climate Disruption International, Report July 2014, 265 p. For the list of cases outside the US, see: http://web.law.columbia.edu/climate-change/non-us-climate-change-litigation-chart ; for the list of cases within the US, see: http://www.arnoldporter.com/resources/documents/ClimateChangeLitigationChart.pdf.
} 
meaning. Indeed, lawsuits have been brought by GHG emitter industries to oppose regulations on emission reductions, as it was the case in France ${ }^{8}$.

At the regional and international levels, beyond the litigation brought before the Court of Justice of the European Union (CJEU) on the functioning of the system for trading GHG emission quotas $^{9}$, several actions have been undertaken, but without success. The most emblematic example is the 2005 petition submitted by Canadian and American Inuit to the Inter American Commission on Human Rights. The Commission, however, decided against hearing the petition, considering that there was insufficient information available to judge whether historic GHG emissions from the United States (US) violated the rights of Arctic indigenous peoples (rights to life, health, property, cultural identity and self-determination). ${ }^{10}$ We should also mention that the island state of Tuvalu has threatened to launch lawsuits against the US and Australia in the International Court of Justice (ICJ) for deciding not to ratify the Kyoto Protocol. Ultimately this threat has not been carried out, particularly due to the absence of a declaration from the US on the acceptance of compulsory jurisdiction. This threat re-emerged in a more politically neutral and procedurally favourable form in the Republic of Palau campaign, supported by a panel of recognized lawyers, which called for the United Nations General Assembly to seek an advisory opinion from the ICJ. ${ }^{11}$ The goal was to obtain its ruling on the obligations under international law imposed on a State to ensure that GHG emitting activities, carried out under a State's jurisdiction or control, do not cause or substantially contribute to damage inflicted on other States. However, this demand did not materialize.

\footnotetext{
${ }^{8}$ French Council of State Judgment: Case 287110, 8 February 2007, Société Arcelor Atlantique et Lorraine [2008] Rec. Lebon-56. See also French Constitutional Council Decision: 2009-599 DC, 29 December 2009, Finance Act 2010 [2009] Rec-218.

${ }^{9}$ N.S. Ghaleigh, Emissions Trading Before the European Court of Justice: Market Making in Luxembourg, in: D. Freestone \& C. Streck (eds.), Legal Aspect of Carbon Trading: Kyoto, Copenhagen and Beyond, 2009, pp. 367388.

${ }^{10}$ See the petition: http://www.inuitcircumpolar.com/inuit-petition-inter-american-commission-on-human-rightsto-oppose-climate-change-caused-by-the-united-states-of-america.html. H. M. Osofsky, The Inuit Petition as a Bridge? Beyond Dialectics of Climate Change and Indigenous Peoples' Rights, American Indian Law Review 2007, pp. 675-697.

${ }^{11}$ See the press conference: http://www.un.org/press/en/2012/120203 ICJ.doc.htm. S. Beck \& E. Burleson, Inside the System, Outside the Box: Palau's Pursuit of Climate Justice and Security at the United Nations, Transnational Environmental Law 2014 (3), pp. 17-29.
} 
The 24 June 2015 decision of the District Court of The Hague in the case Urgenda versus the Netherlands is a continuation of these attempts to obtain climate justice through lawsuits. This climate case was initiated on 12 November 2012 when the NGO Urgenda, along with 886 Dutch citizens, sent a letter calling for the Dutch government to pursue a climate policy that included a GHG emission reduction target of $40 \%$ below 1990 levels by 2020. The State Secretary for Infrastructure and the Environment replied to this letter the following month, in a tone of general agreement with the aims of Urgenda, indicating that her government sought to stay within the limits of a $2^{\circ} \mathrm{C}$ rise in average global temperatures that had been proposed by climate experts. However, the State Secretary added that the climate policy of the Netherlands was part of an international and European context and, therefore, that the State could not decide to raise the level of ambition of its mitigation objective for 2020. Nevertheless, she made a commitment to propose initiatives to partner countries that foster a stable and widely supported policy framework that would lead to sufficient action to keep the long-term perspective of an $80 \%$ to $95 \%$ reduction of GHG emissions by 2050 within reach. Urgenda regarded this time horizon as too distant, asserting that immediate action was needed in terms of strengthened measures to mitigate GHG emissions, and therefore decided to initiate legal proceedings before the Dutch courts on this issue. Urgenda spent one year developing a 144-page argument and then on the 20 November 2013 the Commercial Chamber of the District Court of The Hague was requested to rule on the question of whether the State had acted illegally by not pursuing a more ambitious short-term climate policy. For its part, the State considered that it could not be forced in this direction, particularly with regard to its discretionary power.

This was only one of the obstacles, and by no means the simplest, that the Dutch judge had to address before deciding that the climate policy of the Netherlands was indeed illegal, therefore pointing towards the obligation of the State to raise the minimal level of ambition of its GHG emissions reduction target to $25 \%$ in 2020 compared to 1990 levels.

This injunction, although helping to strengthen action taken by the Netherlands to fight against climate change, may seem insignificant given the global share of GHG emissions derived from this State. ${ }^{12}$ However, this decision of the District Court of The Hague was a turning point for climate justice.

\footnotetext{
${ }^{12}$ In 2010 the Dutch share of global emissions was 0.42\%; while China represented 21.97\%; the United States 13.19\%; the European Union (27 countries) 9.5\%; Brazil 5.7\%; India 5.44\%; and Russia 5.11\%. Per capita emissions in the Netherlands were 12.78 tonnes of $\mathrm{CO}_{2}$-eq. in 2010 , and 11.72 tonnes of $\mathrm{CO}_{2}$-eq in 2012; in 2012
} 
To establish how much of a watershed this event represents, emphasis must be placed on the two parallel movements impacted upon by this decision. The first of these movements is that of climate justice subjectivization, which may inspire other private persons to question the individual climate policy of the State, despite the global nature of climate change (2). The second movement is the initiation of an objectivization of the State's liability regarding climate issues, which could facilitate the involvement of other national, European and international courts in that direction (3).

\section{The Subjectivization of Climate Justice Actors}

Accepting that a private individual is entitled to demand accountability before national courts to challenge a State's climate policy, the District Court of The Hague contributes to the subjectivization of the interests pursued under climate justice (2.1). The Court's decision also allows the subjectivization of the agent of damage associated with climate change, by clearly distinguishing the State as a person with individual liability for climate justice (2.2).

\subsection{Access to Climate Justice for Private Individuals}

Drawing on its constitution, the NGO Urgenda has demonstrated sufficient interest in bringing proceedings to obtain access to a judge (2.1.1), even though it was denied the status as a victim of a human rights violation (2.1.2).

\subsubsection{A Standing Based on the Specific Constitution of the NGO Urgenda}

In the Netherlands, as in other domestic legal orders ${ }^{13}$, a natural or legal person has the opportunity to bring an action before a court if he/she demonstrates a sufficient interest in bringing proceedings in his/her application. ${ }^{14}$ Thus, to bring an action before the court, a foundation or association can reference the protection of the collective interest it pursues, or

\footnotetext{
China emitted 9.04 tonnes of $\mathrm{CO}_{2}$-eq; the US emitted 19.98 tonnes of $\mathrm{CO}_{2}$-eq.; Brazil 15.05 tonnes; India 2.43 tonnes; and Russia 19.58 tonnes.

${ }^{13}$ However, NGO access to the CJEU is more restrictive, and impossible to the ICJ. Regarding access to the European Court of Human Rights, see developments infra under heading 2.1.2.

${ }^{14}$ Article 3:303 of the Dutch Civil Code.
} 
the sum of individual interests of those it represents, ${ }^{15}$ as described in its constitution. Dutch law states, however, that such action is admissible only if the foundation has previously undertaken sufficient effort to establish a dialogue with the defendant to ask for its requirements to be met, ${ }^{16}$ a condition that was clearly fulfilled in this case.

Article 2 of the foundation's by-laws turned out to be decisive, evoking Urgenda's aspiration for a more sustainable society. Specifically, it states an aim to achieve sustainable development and to prevent the consequences of climate change on human societies, particularly, but not only, in the Netherlands. ${ }^{17}$

This collective interest therefore goes beyond national borders, which is important in view of the implications of both global and local climate change. This dual "glocal" dimension was upheld by the Court, which believed that Urgenda, as described in its constitution, sought to protect an interest that by nature transcended national boundaries. ${ }^{18}$ Urgenda could thus base its claims on the fact that emissions from the Netherlands also had implications for people outside Dutch borders. It seemed to suggest that the transnational character of an interest in bringing proceedings can be implicitly recognized, and that litigation brought by an NGO representing the interests of only non-Dutch citizens is possible, in line with the famous Shell Dutch case. ${ }^{19}$

The collective interest defended by Urgenda also features a multi temporal dimension. ${ }^{20}$ The Dutch State does not dispute the fact that Urgenda defends, as stated in its constitution, the rights of the "current" generations of Dutch citizens. In contrast, the issue of the defence of the interests of future generations was more sensitive, but the hypothesis could be advanced ${ }^{21}$ given the existence of precedents recognising the interest of minors ${ }^{22}$. Urgenda

\footnotetext{
${ }^{15}$ Article 3:305a of the Dutch Civil Code.

$16 \$ 4.4$.

$17 \$ 4.7$.

$18 \$ 4.7$.

19 See in particular the District Court of The Hague decisions: Cases C/09/337050, C/09/330891 and C/09/337058, 30 January 2013, and the follow up of this case: https://milieudefensie.nl/english/shell/courtcase/documents

$20 \$ 4.8$.

${ }^{21}$ C. Van Dijk, Civil Liability for Global Warming in the Netherlands, in: M. Faure \& M. Peeters (eds.), Climate change liability, 2011, p. 206, 211 et seq.

${ }^{22}$ Philippines Supreme Court Decision: Case 101083, Decision of 30 July 1993, Oposa v. Factoran [1994] ILM 33-185.
} 
justifies its action on behalf of intergenerational interest on the grounds that present-day State action/inaction regarding GHG emissions reduction will have a significant impact on future generations. The acceptance of this intergenerational dimension of the interest in bringing proceedings represents the Court's endorsement of the scientific argument that delaying action to mitigate climate change will clearly make the challenge more difficult, along with the irreversible nature of the consequences of past and current GHG emissions.

The District Court of The Hague thus recognized that the collective concern contained within Urgenda's constitution gave it an interest in bringing proceedings. Conversely, it did not recognize Urgenda to be a victim of a violation of human rights.

\subsubsection{A Standing Not Based on the Status of Victim of Human Rights Violations}

The rise of human rights as one of the responses to growing environmental degradation is well established, ${ }^{23}$ particularly due to individuals and NGOs having access to judges. However, there are limitations to the contribution of human rights that arise due to antagonism between the rights of individuals and collective interests. ${ }^{24}$ Thus, Article 34 of the European Convention on Human Rights states that the European Court of Human Rights (ECHR) may receive applications from any person, NGO or group of individuals claiming to be the victim, directly or indirectly, ${ }^{25}$ of a violation of the Convention by a State party. ${ }^{26}$ The determination of the victim status is therefore crucial to obtain access to the Strasbourg Court, a status that Urgenda sought to establish, not only for itself but also for the 886 people involved in its work.

In its argument, the NGO emphasized the fact that climate change affected living conditions and thus human health, which in its view is contrary to Article 2 (right to life) and Article 8 (right to a private and family life) of the Convention. The Dutch State rejected the

\footnotetext{
${ }^{23}$ S. Humphreys, Human Rights and Climate Change, 2009. O. Quirico \& M. Boumghar (eds), Climate Change and Human Rights: an International Law Perspective, 2015.

${ }^{24}$ F. Francioni, La dimension environnementale des droits de 1'Homme entre individualisme et intérêt collectif, in: D. Alland et al. (eds.), Unity and diversity of international law, Essays in Honour of Professor Pierre-Marie Dupuy, 2014, pp. 950-965.

${ }^{25}$ ECHR Judgments: Case 37330/02, 13 September 2006, Defalque v. Belgium, §46 and Case 26698/05, 27 March 2008, Tourkiki Enosi Xanthis and others v. Greece, §38.

${ }^{26}$ ECHR Judgment: Case 72377/01, 11 July 2006, SARL du Parc d'Activités de Blotzheim v France, $\$ 20$.
} 
application of these two Articles because of the "absence of a real threat" of climate change, ${ }^{27}$ in short, the absence of climate damage.

In this respect it should be noted that the ECHR permits requests from potential victims. ${ }^{28}$ Such individuals may be destined to undergo a violation of their rights. In this instance, the applicant must produce plausible and conclusive evidence of a violation from which he or she would personally suffer the effects. In environmental litigation, there has already been an occasion where the ECHR could have ruled on the potential victim status, ${ }^{29}$ however, climate change presents serious challenges to the establishment of the causal link between the damage caused and the injury suffered. ${ }^{30}$

The District Court of the Hague avoided having to rule on this issue by deciding not to examine the interest in bringing proceedings from the 886 citizens in terms of their status as victims of human rights violations. The Court considered that it did not have sufficient information about these individual applicants to grant this status. ${ }^{31}$ Regarding Urgenda as an organization, the Dutch judge pointed out that, unlike a natural person, the integrity of a legal person could not be violated and that the private life of a legal person could not be modified. ${ }^{32}$ Therefore, Urgenda could not demonstrate that the alleged violation of Articles 2 and 8 of the Convention was causing it harm and that it had a legitimate and personal interest for this damage to end. ${ }^{33}$ Neither did the Dutch judge, based on a decision of the ECHR, ${ }^{34}$ permit Urgenda to endorse the potential victim status of the 886 citizens associated with its work.

While the Dutch judge failed to show a great deal of audacity by refusing to base Urgenda's interest in bringing proceedings on the alleged violation of human rights, he did

\footnotetext{
$27 \S 3.3$.

${ }^{28}$ ECHR Judgments: Case 14038/88, 6 September 1978, Klass and others v Germany and Case 14038/88, 7 July 1989, Soering v United Kingdom.

${ }^{29}$ In the ECHR Judgment: Case 17381/02, 5 June 2007, Lemke v. Turkey, the Court has broadly interpreted the status of "victim".

${ }^{30}$ A. Gouritin, La jurisprudence de la Cour Européenne des Droits de l'Homme sur les obligations positives en matière environnementale peut-elle s'appliquer aux changements climatiques?, in: C. Cournil \& C. ColardFabregoule (eds.), Les changements climatiques et les défis du droit, 2010, pp. 255-256.

31 \$4.109.

${ }^{32}$ ECHR Judgment: Case 73235/12, 12 May 2015, Identoba et al. v. Georgia, §40 to 43.

$33 \$ 4.45$.

${ }^{34}$ ECHR Judgment: Case 19221/08, 29 September 2009, Van Melle v the Netherlands.
} 
however go beyond the admissibility stage of the case to rule on the substance and, in an unprecedented step, singled out the State as an individual liable to climate justice.

\subsection{Identification of the State as Individually Liable to Climate Justice}

Through the acknowledgement of a sufficient causal link between the GHG emissions of the Netherlands and global climate change and its impacts on the Dutch climate, ${ }^{35}$ both present and future, The District Court of The Hague managed to overcome the major obstacle to the establishment of the State's individual responsibility to address a global problem (2.2.1). Although a less controversial issue, this decision also overcame the difficulty of attributing GHG emissions to the State (2.2.2).

\subsubsection{The Causal Link between State's Emissions and Climate Change}

In the context of an action for liability in the field of climate change, the establishment of the causal link between the defendant's conduct and the damage caused to the applicant is probably the most important barrier. Even if one agrees with the analysis of the IPCC according to which anthropogenic GHG emissions are causing climate change, the global nature of the causes and effects of the problem makes such a causal link difficult to establish. Indeed, it is impossible to consider that a particular source of GHG emissions causes a particular harm.

In essence, this is the stance taken by the Dutch State to challenge Urgenda's interest in bringing proceedings as part of an action for damages, arguing that even if the Court granted Urgenda's request, it would not prevent the damage it incurs as a result of climate change. ${ }^{36}$

In other cases, this argument has prevented the substantive analysis of claims. For example, in the Comer vs. Murphy Oil ${ }^{37}$ case, in which the Southern District of Mississippi Court stated: "there exists a sharp difference of opinion in the scientific community concerning the cause of global warming, and I foresee daunting evidentiary problems (...) to prove (...) the degree to which (...) the actions of any individual (...) company (...) contribute

\footnotetext{
${ }^{35} \$ 4.90$.

${ }^{36} \$ 4.78$.

${ }^{37}$ Southern District of Mississippi Court Judgment: Case 1:05-CV-436 LTD-RHW, Comer et al. vs. Nationwide Mutual Insurance Co. et al. [2006] WL 1066645.
} 
(...) to global warming (....." ${ }^{38}$ However, in this case the Court of Appeal considered that the defendant's contribution to the harm was sufficient to establish the requisite causal link, at least to establish the applicant's interest in bringing proceedings. ${ }^{39}$

The District Court of The Hague also positioned itself on the grounds of the contribution to the damage, stressing that "the Dutch greenhouse emissions have contributed to climate change and by their nature will also continue to contribute to climate change"40 and that "emission reduction therefore concerns both a joint and individual responsibility of the signatories to the UN Climate Change Convention". "However, it did not go as far as to give formal recognition to a joint and several liability. ${ }^{42}$

Similarly, it avoided pushing the argument to the extreme by trying to identify exactly how GHG emissions from the Netherlands were influencing climate change, which could have been the case if it had sought to establish strictly proportionate liability. To avoid having to do so, it mobilized the international commitments of the Netherlands and the principle of equity, considering that "in view of a fair distribution, the Netherlands, like other Annex I countries, has taken the lead in taking mitigation measures and has therefore committed to a more than proportionate contribution to reduction."

\subsubsection{The Attribution to the State of Emissions from its Territory}

The issue of the causal link between a State's action or omission and climate change also raises the issue of the attribution to the State of GHG emissions arising from its territory. The Dutch State has argued that it cannot be considered as "one of the causers of an imminent

\footnotetext{
${ }^{38}$ Ibid., p. 4.

${ }^{39}$ US Court of Appeal for the 5th circuit Judgment: Case 12-60291, Comer et al vs. Murphy Oil USA inc. et al., [2009] WL 3321493-6. In this sense, see also Supreme Court of the US Judgment: Case 05-1120, Massachusetts vs. EPA [2007], 127 S.Ct.-1438. The standard of proof of the causal link at the merit stage is higher than for establishing standing.

${ }^{40} \S 4.90$. For a breakdown of the reasoning at the scale of the EU and the businesses located there, leading to the rejection of the argument relating to "carbon leakage", see $\$ 4.81$.

${ }^{41} \$ 4.79$.

${ }^{42}$ For an argument in favour of such solution, see M. Faure \& A. Nolkaemper, International Liability as an Instrument to Prevent and Compensate for Climate Change, Stanford Environmental Law Journal 2007 (26), p. 123,165 et seq.

43 \$4.79.
} 
climate change, as it does not emit greenhouse gases."44

However, the District Court of The Hague has not found it difficult to dismiss this argument. Clearly, GHG emissions arising from the territory of the Netherlands do not derive from the State as such. Rather they are the result of the behaviour of Dutch citizens who drive cars, heat homes and consume imported goods, as well as from companies that produce certain goods, etc. Nevertheless, it is possible to attribute these emissions to the State because it has the means to influence these private GHG emissions, to the extent that it is able to control the level of GHG emissions through the adoption of regulations or authorization procedures. Thus, these private GHG emissions can be attributed to the State, bringing the issue of State responsibility into play. ${ }^{45}$

The principle of the attribution to the State of the conduct of private individuals within its jurisdiction and on its territory is well established in international law, ${ }^{46}$ including international environmental law ${ }^{47}$. This idea also refers to the civil law concept of vicarious liability, which refers to a situation where one party is held responsible for the damages caused by others over which that party has responsibility. To further consolidate its position, the District Court of The Hague also referred to the international commitments of the Netherlands, against the backdrop of the pacta sunt servanda principle. ${ }^{48}$

Finally, the Court addressed the question of the temporal dimension of GHG emissions, with regard to future, not past, emissions, considering that "the excess greenhouse gas emission in the Netherlands that will occur between the present time and 2020 without further measures, can be attributed to the State."49

The Court was therefore able to establish the subjective element of the act for which liability was incurred, determining that the State was an individual that must respond to Urgenda's demands. However, this subjective element alone was not sufficient to entail State liability, it was only through its association with the objective element of the act for which liability was incurred, that the subjective element became fully significant.

\footnotetext{
${ }^{44} \$ 4.66$.

45 Ibid. and $\$ 4.87$.

${ }^{46}$ International arbitral Award: Case Island of Palmas (USA / Netherlands), 4 April 1928 [2006] Rec. II-829.

${ }^{47}$ International arbitral awards: Case Trail smelter (United States vs. Canada), 16 April 1938 and 11 March 1941 [2006] Rec. III-1905.

$48 \$ 4.66$.

$49 \$ 4.87$.
} 


\section{Objectivization of State's Climate Liability}

There are different interpretations of the objective nature of liability. In this commentary the expression is used to refer to the assumption of responsibility based on the commission of a wrongful act, conceived objectively, as a breach of the law, making it easier for the victim to fulfil his or her task in terms of the provision of evidence. The misconduct was not alien to the Dutch law of civil liability, however, it was not on these grounds that the judge chose to base his decision, but rather on the grounds of a damaging event which, under the law or generally accepted principles, could be attributable to the State due to the obligations it has liability for. ${ }^{50}$ To do so, the judge had to first establish the fact that climate policy in the Netherlands is governed by a legal obligation of the State (3.1). This allowed him not only to reject the argument that controlling the GHG emissions reduction trajectory of the Netherlands was not purely a matter of political choice, but also to consider that the State was negligent by not making every effort to comply with this obligation, and this negligence entailed the involvement of its responsibility ${ }^{51}(3.2)$.

\subsection{The Basis of the Unlawfulness of the State's Climate Policy}

To bring the civil liability of the State into play, ${ }^{52}$ Urgenda had to establish that the State had acted (or failed to act) illegally, violating either a right claimed by Urgenda or a law, or by failing to exhibit what can be considered under the unwritten "due care" principle as adequate social behaviour. ${ }^{53}$ While the judge dismissed the first two assumptions (3.1.1), he retained, however, the third one (3.1.2).

\subsubsection{The Impossibility of Founding the case on International Law, Human Rights and the \\ Constitution}

\footnotetext{
${ }^{50}$ Article 6:612, paragraph 3 of the Dutch Civil Code.

${ }^{51}$ Dutch law does not allow tort actions brought by legal persons to seek compensation for damage (Article 3: $305 \mathrm{a} 3$ of the Dutch Civil Code). Such action leads simply to a declaratory judgement and possibly an order, comparable to that which would result from the bringing into play of the State international responsibility or from review procedures before the CJEU and domestic judges.

${ }^{52}$ Article 6:612, paragraph 1 of the Dutch Civil Code.

${ }^{53}$ Article 6:612, paragraph 2 of the Dutch Civil Code.
} 
At first Urgenda attempted to base the illegality of the State's omission on a breach of the European Convention on Human Rights ${ }^{54}$. Neither did the Court retain a legal foundation based on Article 21 of the Constitution ${ }^{55}$ due to the general and imprecise nature of this provision, which leaves a major discretionary power to the State. ${ }^{56}$ Finally, the Court rejected the foundations drawn from international law. In this regard it stated that the provisions of the United Nations Framework Convention on Climate Change (UNFCCC), of the Kyoto Protocol and the principle of non-harmful use of territory were not endowed with direct effect, so that a private individual could not rely on these provisions before the domestic courts. ${ }^{57}$

No doubt aware of the influence that its decision could have on other jurisdictions, it preferred to use these international standards more effectively, not referring to them directly but more strategically, as a background element to be taken into account in interpreting and applying internal law. ${ }^{58}$ In essence, it justified this position in the light of the principles according to which regularly concluded international agreements must be executed by the parties in good faith ${ }^{59}$ with consistent interpretation ${ }^{60}$ but without expressly making reference to them. The District Court of The Hague subsequently specified that this reasoning also applied to European Union (EU) law $^{61}$ and European Convention on Human Rights. ${ }^{62}$ In doing so the Dutch judge admitted the "indirect justiciability" 63 of international and European standards, allowing him to more easily establish the illegality of the State's conduct in terms of the violation of its duty of care. ${ }^{64}$

\subsubsection{Foundation on the Duty of Care in Light of the Rejected Foundations}

\footnotetext{
${ }^{54}$ See development supra heading 2.2.2. and $\$ 4.45$.

55 "It shall be the concern of the authorities to keep the country habitable and to protect and improve the environment".

$56 \$ 4.36$.

$57 \$ 4.42$.

$58 \$ 4.43$.

59 Ibid.

${ }^{60}$ Ibid.

${ }^{61} \S 4.44$.

$62 \$ 4.46$.

${ }^{63}$ The Court uses in this regard the expression "reflex effect" (\$4.43).

${ }^{64} \S 4.52$.
} 
To determine whether, as claimed by Urgenda, the State has a duty of care in respect of climate policy, the judge used a set of criteria ${ }^{65}$ inspired by the case law on civil liability for endangering others ${ }^{66}$, as well as the objectives and principles of the UNFCCC and of the Treaty on the Functioning of the EU in relation to environmental issues. ${ }^{67}$ The criteria related to the damage incurred and to the cost-effectiveness of the measures necessary for its prevention are especially interesting, to the extent that they encouraged the judge to apply the precautionary principle. The Court's interpretation of the precautionary principle proved decisive, firstly, in affirming the obligation of the State to protect its citizens from the consequences of climate change, thus framing its discretionary power under Article 21 of the Constitution, ${ }^{68}$ and secondly, by giving substance to the State's duty of care in relation to climate matters.

As part of the determination of whether the State should be subject to a duty of care regarding climate issues, the Dutch judge firstly mobilized three criteria related to the damage incurred. The challenge here is that, in the field of climate change, the damage is uncertain. ${ }^{69}$ The judge circumvented this problem by not considering damage as the basis for the liability of the Netherlands, but rather as an index that could enable the assessment of the existence of a State's duty of care in climate matters, the ignorance of which would, as such, constitute a basis for the State's liability for negligence. This way of thinking endows liability with a preventive provision. In this context, the consideration of damage that is uncertain is more easily conceivable. It amounts to asking if - given the importance, the knowledge and the probability of the realization of the damage incurred - it can reasonably be considered that the State has a duty of care to prevent its realization, which was the case in this instance,

\footnotetext{
$65 \$ 4.63$.

${ }^{66}$ Supreme Court of the Netherlands Judgment: Case AB7079, Kelderluik, 5 November 1965 [1966] NJ-136.

${ }^{67}$ Thus, the Court refers in turn to equity ( $\$ 4.56$ and 4.57$)$, sustainable development ( $\$ 4.56$ and 4.59$)$, the high level of environmental protection and prevention of environmental damage ( $\$ 4.60$ and 4.61$)$, the precautionary principle $(\S 4.56,4.58,4.60$ and 4.61$)$ to take into account scientific and technical data, benefits and burdens which may result from action or lack of action, and to economic and social development (\$4.62). $68 \$ 4.74$.

${ }^{69}$ If an uncertain damage cannot base state of necessity as a cause of exemption from international responsibility (ICJ judgment: Case Gabcikovo-Nagymaros, 25 September 1997 [1997] Rec.-7, §54), an internationally wrongful act is sufficient to entail international responsibility, the potential damage being only considered for establishing standing. Likewise, if the extra-contractual liability of the EU can only be established to redress a real damage, it does not enter into consideration within actions for failure to act or for annulment.
} 
especially in view of IPCC reports. The precautionary principle was therefore mobilized to clarify the boundaries of the State's duty of care to prevent the realization of uncertain damage. $^{70}$

The last two criteria relate in essence to the evaluation of the cost of the measures to be undertaken, in isolation, and also with regard to the benefits of the measures in preventing the realization of the damage, the effectiveness of these measures and the technical feasibility of their implementation. ${ }^{71}$ These criteria mobilize another aspect of the precautionary principle related to finding the right balance, or the right proportions, between the objective of preventing uncertain damage and the resources deployed for this purpose. ${ }^{72}$ Concluding that these criteria also support the argument in favour of a State's duty of care in the field of climate issues, the Court once again based itself on the IPCC and the United Nations Environment Programme reports, considering that mitigation measures had to be taken at the present time and in priority to adaptation measures, for reasons of cost effectiveness. ${ }^{73}$ The Court also considered that the State had not demonstrated that the level of ambition of its climate policy was justified by economic considerations, ${ }^{74}$ or that raising the ambition would be an impossible burden to meet. ${ }^{75}$ Finally, according to the Court, the principle of equity required the consideration of a reasonable distribution of the costs of taking action between present and future generations. ${ }^{76}$

The Court concluded that, on the matter of the climate, the State did have a duty of care. This line of reasoning taken by the District Court of The Hague could easily be applied by

\footnotetext{
${ }^{70}$ In this sense, see ITLOS Advisory Opinion: Case 17, Responsibilities and obligations of States sponsoring persons and entities with respect to activities in the Area, 11 February 2011,§131: "the duty of care (...) requires States (...) to take all appropriate measures to prevent damage (...) 'including in' situations where scientific evidence as to the scope and potential adverse effects of the activities concerned are insufficient, but where there are credible indications of potential risks". Also, ECHR Judgment: Case 67021/01, Tatar v. Romania, 27 January 2009, §109: "the precautionary principle recommends that States do not delay the adoption of effective and proportionate measures to prevent a risk of serious and irreversible damage to the environment in the absence of scientific or technical certainty".

$71 \$ 4.67$ to 4.82 .

${ }^{72}$ See in particular, Mr. Haritz, Liability with and liability from the precautionary principle in climate change cases, in: M. Faure \& M. Peeters (eds.), supra note 22, p. 15, 27 et seq.

$73 \$ 4.70$ and 4.71 .

$74 \$ 4.77$ and 4.82 .

$75 \$ 4.77$.

$76 \$ 4.76$.
} 
another jurisdiction, insofar as the State's duty of care is a principle that runs through various branches of law. ${ }^{77}$ However, to give substance to this duty of care in the context of climate change, the Court mobilized the precautionary principle, which also now forms part of many legal systems. Finally, the Court managed to obtain concrete results through the mobilization of an international and European legal framework with relevance beyond the Netherlands.

\subsection{The Qualification of State Neglect}

Once the Court had determined that the State has a duty of care regarding the climate, which the judge was able to give substance to with the precautionary principle, it could dismiss the objection related to the political nature of the State's decisions in terms of its GHG emission reduction target (3.2.1). In the final part of its reasoning the Court established what constituted a standard of due care in respect of the climate, before concluding that the GHG emissions mitigation policy of the Netherlands did not comply to this standard and, therefore, constituted negligence for which the State had to be held responsible (3.2.2).

\subsubsection{Dismissal of the Objection related to the Principle of Separation of Powers}

In support of its argument against Urgenda's action aimed at contesting the Netherlands mitigation objective, the State evoked the violation of the separation of powers principle. According to the State, the political nature of a State's climate policy choices did not fall under the discretion of the judge.

The Court gave this highly sensitive argument an attentive hearing, ${ }^{78}$ firstly recalling that this founding principle of the organization of public authorities, derived from the trias politica theory, had led to the emergence of the rule of law. The Court then pointed out that Dutch law did not have a full separation of powers between the executive and the judicial functions and, finally, that even if each authority has its own objectives, each also has

\footnotetext{
${ }^{77}$ For the consecration of this principle as international customary law, see especially ICJ Judgment: Case paper and pulp plant on the River Uruguay (Argentina v. Uruguay), 20 April 2010, [2010], Rec.-14, §131.

${ }^{78}$ In the United States, in some cases, the judge used a body of evidence to consider by contrast that the appreciation of the federal climate policy was political, so that he could not deal with matters under the principle of separation of powers (See for instance US District Court for the Northern District of California Judgment: Case C06-05755, California v. General Motors Corp., [2007], §2). For a different view, see US Court of Appeals for the 2nd circuit Judgment: Case Connecticut et al. v. American Electric Power Company Inc. et al., [2009].
} 
responsibilities. The judicial function is responsible for settling disputes and framing the actions of the State's political organs. Such actions must be examined by an independent court $^{79}$ in accordance with the very principle of the control of legality. ${ }^{80}$

The Court thus considered that Urgenda's demand fitted perfectly into its judicial assignments and that the climate policy of the Netherlands required judicial review. ${ }^{81}$ In this regard, the Court considered that it did not need to consider the political implications of its decision within the framework of the $21^{\text {st }}$ Conference of the Parties (COP 21) international negotiations, under which the State claimed to retain flexibility. ${ }^{82}$ However, it asserted that its decision would be binding for the Netherlands, including in this context. ${ }^{83}$

The judge's decision did not order or prohibit the application of a particular measure or the adoption of a specific policy, the State retained its freedom ${ }^{84}$ on how it complies with the standard of care set by the Court.

\subsubsection{Setting a Standard of Due Care in relation to Climate Change}

The Dutch court did not simply decide that the State had a duty of care regarding the climate. It also set precisely the standard required in this area. It thus ruled on the level of this obligation, indicating that the State had a "serious" duty of care ${ }^{85}$ and that it must demonstrate a "high level" of care that would result in the establishment of an adequate and effective

\footnotetext{
79 §4.95. Compare with the ICJ's position that "whatever its political aspects, the Court cannot refuse to admit the legal character of a question which invites it to discharge an essentially judicial task, namely, an assessment of the legality of the possible conduct of States with regard to the obligations imposed upon them by international law" (ICJ Advisory Opinion: Case Legality of the threat or use of nuclear weapons, 8 July 1996 [1996] Rec-226, $\S 13)$.

${ }^{80} \$ 4.97$.

$81 \S 4.98$.

82 \$4.98. Conversely, note on this point, the ECJ refused to take into account the provisions of GATT to assess the legality of a Community regulation (ECJ Judgment: Case C-280/93, of 5 October 1994, Germany v. Council, 5 October 1994 [1994] Rec. I-4973, §109), since the characteristics of these agreements leave constant room for negotiation, and since this "would deprive the legislative or executive organs of the Community of the scope of manoeuvre enjoyed by their counterparts in the Community's trading partners" (ECJ Judgment: Case C-149/96, Portugal v. Council, 23 November 1999, [1999] Rec. I-8385, §46).

$83 \$ 4.100$.

${ }^{84} \S 4.401$.

$85 \$ 4.65$.
} 
statutory and instrumental framework to reduce the GHG emissions of the Netherlands. ${ }^{86}$ Finally, the judge declared that the State's duty of care on climate implied that as many mitigation actions as possible were to be undertaken, as quickly as possible. ${ }^{87}$

The Court went even further, putting figures and dates in terms of consequences onto otherwise general statements. In this regard, the judge pursued the following reasoning: to prevent dangerous climate change, the concentration of GHGs in the atmosphere must be maintained at less than 450 parts per million, because under this scenario, according to IPCC forecasts, there is the best chance of avoiding an average global temperature rise of over $2{ }^{\circ} \mathrm{C}$, beyond which irreversible damage will be realized. However, the current target of a $17 \%$ reduction, compared to 1990 levels, in the GHG emissions of the Netherlands by 2020 is insufficient to comply with this scenario. An appropriate reduction for developing countries of between $25 \%$ and $40 \%$ by 2020 , compared to 1990 , having been set out at the Cancun Agreements. Accordingly, the judge concluded that the GHG emissions mitigation policy in the Netherlands, by not pursuing a reduction of at least $25 \%$ by 2020 compared to 1990 levels, was contrary to the State's duty of care to the climate.

In doing so, it dismissed two arguments submitted as a defence by the State. First, it rejected the argument that, by fixing its current GHG emission reduction target, the Netherlands was acting in accordance with EU law, pointing out that the targets assigned to each Member State constituted a minimum. Indeed, although it may be difficult for the Netherlands to take action regarding the objectives of sectors covered by the trading system that is harmonized across the EU, the State has greater manoeuvre room in other sectors. ${ }^{88}$ The Court then rejected the argument that the 2030 time horizon objective of the EU and the Netherlands did in fact correspond with the IPCC scenario, considering that the delaying of GHG emissions reductions was too risky because it was not supported by politically recognized scientific research. ${ }^{89}$

While Urgenda, as a legal entity, was unable to claim compensation for its loss before the Dutch civil judge, it did however achieve much more. For the first time ever, action for liability had shown that a State was legally obliged to adopt a quantified and timetabled development trajectory to reduce its GHG emissions, on the basis of objective scientific

\footnotetext{
${ }^{86} \$ 4.66$.

$87 \$ 4.73$.

${ }^{88} \$ 4.80$.

${ }^{89} \S 4.85$.
} 
considerations with the perspective that we must prevent climate change that is dangerous to humans.

\section{Conclusion}

In line with other Dutch decisions, ${ }^{90}$ the application supported by Urgenda is having a decisive effect on environmental justice. The unprecedented nature of this decision opens up interesting prospects for its potential political implications in the context of the ongoing international negotiations, and also in terms of the "dialogue of judges" that it could initiate.

Importantly, however, the Dutch government decided to appeal against the decision. Although the filling of an appeal does not undo the State obligation to comply with the Court's ruling, the political cost of such a move, just a few months before the COP 21, should have been dissuasive. An appeal send out a contradictory signal given that the Netherlands engages in debates with many States, including those within the EU, to encourage the setting of ambitious goals. Conversely, there is a strong incentive for the Netherlands to use this decision, and possibly other similar rulings from national or international courts, in support of advocating for an increase in mitigation commitments from the parties referred to in Appendix I of the Convention, and even from other high GHG-emitting States, at the same time as the Paris negotiations. ${ }^{91}$ While it is by no means certain that all States concerned will respond positively to this argument, those currently subject to similar contentious initiatives ${ }^{92}$ could, on the other hand, be particularly sensitive, perhaps even going further by giving consideration to the idea of raising the ambition level of their adaptation policies ${ }^{93}$. If, the challenge of this ruling was successful, it is possible that Urgenda might take the case to the ECHR, taking the

\footnotetext{
${ }^{90}$ See the Shell cases, supra note 20 , and other more localized actions.

${ }^{91}$ It should be noted, however, that the entry into force of the agreement expected in Paris will not take place before 2020, so that the order of the District Court of The Hague, formulated for 2020, will only have an indirect effect on the ambition of mitigation targets that will appear in the Paris agreement.

92 In April 2015, some 9000 co-applicants and the NGO Klimaatzaak have filed a lawsuit before the Court of First Instance of Brussels to force the Belgian government to reduce its GHG emissions by $40 \%$, compared to 1990 levels, by 2020 and by $87.5 \%$ by 2050 . A decision is expected during 2016 (http://www.klimaatzaak.be/en/). Other actions against Australia, England, France, Ireland, Italy and Norway are under consideration.

93 In this respect, see: Lahore High Court judgment: Case 25501/2015, of 14 September 2015, Leghari versus Federation of Pakistan, where the Court ordered Pakistan to take action on climate change.
} 
view that this could be another opportunity to establish recognition of the status of a direct or indirect victim of a violation of the Convention.

The objectivization of responsibility, in which the decision of the District Court of The Hague has participated, induces an improvement of the burden of proof borne by the victim. This could encourage other actions for liability to prevent damage caused by climate change to be brought before domestic or European courts and also before international judges ${ }^{94}$, bringing into play the international responsibility of the State. Meanwhile, the culmination of the subjectivization of climate justice actors would suppose to cross another step by bringing into play, not only the individual liability of the State, but also that of high GHG-emitting companies.

\footnotetext{
${ }^{94}$ See the public lecture delivered by the Professor P. Sands at the UK Supreme Court, the 17 September 2015 , on the role of international law and judges in addressing legal issues relating to climate change, available at https://www.supremecourt.uk/docs/professor-sands-lecture-on-climate-change-and-the-rule-of-law.pdf.
} 